The Effectiveness of ICT Training in the Work Area (PDWK) on Increasing the Competence of MTs Teachers in Bojonegoro Regency

\title{
Efektivitas Pelatihan TIK Di Wilayah Kerja (PDWK) Terhadap Peningkatan Kompetensi Guru MTs Di Kabupaten Bojonegoro
}

\author{
Ani Nur Hidayati \\ Balai Diklat Keagamaan Surabaya \\ anihidayati2203@gmail.com
}

\begin{abstract}
The purpose of this study was to analyze the effectiveness of ICT Training in the Work Area (PDWK) on increasing the competence of MTs teachers in Kab. Bojonegoro. This type of research is pre-experimental research design with one group preset-postest design. Data on participant activities were analyzed descriptively, data on mastery of the concept of using ICT were analyzed using paired t-test and data on participants' responses to training were analyzed descriptively. The results showed: [1] The participant's activity with an average observation result of $79.14 \%$ with very high criteria; [2] The criteria for mastery of the concept of using ICTs obtained a p-value of $0.000<0.05$, it can be stated that ICT Training in the Work Area (PDWK) is effective in increasing teacher competence; [3] The response of the participants was positive, indicated by the mean response rate of $79.14 \%$ with very high criteria.
\end{abstract}

Keywords: training, competence, teacher

\section{ABSTRAK}

Tujuan penelitian ini adalah untuk menganalisis efektivitas Pelatihan TIK di Wilayah Kerja (PDWK) terhadap peningkatan kompetensi guru MTs di Kab. Bojonegoro. Jenis penelitian ini adalah pre-experimental dengan desain penelitian one group pretset-postest design. Data tentang aktivitas peserta dianalisis secara deskriptif, data tentang penguasaan konsep pemanfaatan TIK dianalisis dengan uji-t berpasangan dan data tentang respon peserta terhadap pelatihan dianalisis secara deskriptif. Hasil penelitian menunjukkan: [1] Aktivitas peserta dengan rata-rata hasil pengamatan sebesar 79,14\% dengan kriteria sangat tinggi; [2] Kriteria penguasaan konsep tentang pemanfaatan TIK diperoleh nilai $p$-value sebesar $0,000<0,05$, dapat dinyatakan Pelatihan TIK di Wilayah Kerja (PDWK) efektif terhadap peningkatan kompetensi guru.; [3] Respon peserta positif, ditunjukkan dengan rerata hasil respon 79,14 \% dengan kriteria sangat tinggi.

Kata Kunci: pelatihan, kompetensi, guru

\section{PENDAHULUAN}

Guru adalah pendidik profesional dengan tugas utama mendidik, mengajar, membimbing, mengarahkan, melatih, menilai, mengevaluasi peserta didik pada pendidikan jalur menengah, jalur formal, non formal dan informal. Guru adalah salah satu di antara faktor pendidikan yang memiliki peranan yang paling strategis, sebab gurulah sebetulnya yang paling menentukan di dalam terjadinya proses belajar mengajar (Nuraeni \& Riyanto, 2017). Untuk menjadi guru profesional seorang guru harus kompeten.

Didalam (UU RI No. 14 Th. 2005 tentang Guru dan Dosen, 2006) kompetensi adalah seperangkat pengetahuan, keterampilan, dan perilaku yang harus dimiliki, dihayati, dan dikuasai 
oleh guru atau dosen dalam melaksanakan tugas keprofesionalan. Di dalam pasal 10 ayat (1) (UU RI No. 14 Th. 2005 tentang Guru dan Dosen, 2006) dinyatakan bahwa kompetensi guru meliputi kompetensi paedagogik, kompetensi kepribadian, kompetensi sosial, dan kompetensi profesonal yang diperoleh melalui pendidikan profesi.

Kompetensi merupakan suatu kemampuan yang mutlak dimiliki seseorang dalam setiap bidang profesi yang ditekuninya. Kompetensi merupakan kecakapan dan keterampilan yang melekat pada diri manusia atau pemilikan pengetahuan, keterampilan dan kemampuan seseorang (Roestiyah, 1999). Kompetensi itu menunjukkan kepada tindakan rasional yang dapat mencapai tujuan-tujuannya secara memuaskan berdasarkan kondisi prasyarat yang diharapkan (Saud, 2009)

Hasil uji kompetensi guru secara nasional menunjukan masih rendahnya penguasaan guru pada kompetensi pedagogik dan profesional, ditunjukkan dengan hasil rerata nilai uji kompetensi guru pada jenjang SMP tahun 2015 adalah 44,16, kemudian hasil uji kompetensi guru pada tahun 2016 adalah 65,33 dan hasil uji kompetensi guru pada tahun 2017 adalah 67,76 (Paramita, 2021). Kondisi tersebut memprihatinkan mengingat rerata yang dicapai masih berada di bawah standar minimal yang ditetapkan yaitu 75.

Meskipun Uji Kompetensi Guru tidak dapat dijadikan sebagai satu-satunya indikator kualitas guru, hasil UKG tetap menunjukkan bahwa banyak guru di Indonesia belum punya minimum kompetensi yang dibutuhkan untuk memfasilitasi pembelajaran yang berkualitas. Peningkatan kompetensi guru dalam lingkup lebih luas dapat ditingkatkan melalui berbagai alternatif seperti yang ditawarkan oleh Direktorat Jenderal Pendidikan Dasar dan Menengah Departemen Pendidikan Nasional salah satunya melalui Program pelatihan. Hal tersebut dilakukan karena didasarkan masih adanya guru yang kurang kompeten, dan dibalik itu akan terciptanya tenaga pengajar/guru yang kompeten sehingga mampu mengatasi persoalan yang dihadapi.

Balai Diklat Keagamaan Surabaya sebagai lembaga pendidikan dan pelatihan berkewajiban untuk mempersiapkan guru agar siap menjadi pendidik yang sesuai dengan tuntutan jaman. Pelatihan merupakan salah satu usaha untuk mengurangi atau menghilangkan kesenjangan antara kemampuan sumber daya manusia dengan kebutuhan yang dikehendaki oleh instansi. Instansi yang memiliki kepedulian tinggi akan menggunakan pelatihan untuk meningkatkan kemampuan profesionalisme pegawainya. Melalui program pelatihan diharapkan adanya peningkatan pengetahuan (knowledge), keahlian (skill), kemampuan (ability), sikap (attitudes) dan perilaku (behaviour). (Faustino Cardoso, 2003)

Berdasarkan kondisi inilah kegiatan yang dilakukan balai diklat adalah melaksanakan Pelatihan di Wilayah Kerja (PDWK) sebagai suatu upaya membantu membekali pengetahuan dan ketrampilan yang cukup bagi guru dalam merancang maupun mengelola kegiatan pembelajaran berbasis TIK hal ini sejalan dengan kompetensi profesional guru, maka perlu dilakukan upaya untuk meningkatkan kompetensi guru melalui Pelatihan TIK di Wilayah Kerja (PDWK).

Pelatihan TIK di Wilayah Kerja (PDWK) dilaksanakan di tempat kerja dengan durasi 60 jam pelajaran, kegiatan ini dilaksanakan di Kabupaten Bojonegoro, sasaran pelatihan guru MTs yang ada di wilayah Kab. Bojonegoro didasarkan dari hasil analisis yang diperoleh melalui kegiatan Analisis Kebutuhan Diklat (AKD) Tahun 2020 sekaligus memenuhi surat permohonan yang dikirimkan oleh kantor kementerian agama Kab. Bojonegoro kepada balai diklat.

Peserta diberikan materi berupa teori $30 \%$ dan praktek $70 \%$ yang disampaikan secara bersamaan. Adapun materi yang diberikan pada pelatihan kali ini adalah materi yang terkait dengan kompetensi profesional guru mengenai pemanfaatan TIK dalam pembelajaran yang meliputi; 1] pembuatan konten video interaktif dalam pembelajaran, 2] pembuatan presentasi menarik menggunakan aplikasi popular, 3] pembuatan kelas online menggunakan aplikasi populer, 4] pembuatan blog sebagai portofolio 
menggunakan aplikasi populer.

Rumusan masalah dalam penelitian ini adalah "Bagaimana efektivitas Pelatihan TIK di Wilayah Kerja (PDWK) terhadap peningkatan kompetensi guru MTs di Kab. Bojonogoro"?

Berdasarkan hal tersebut maka tujuan penelitian ini adalah untuk mengetahui efektivitas Pelatihan TIK di Wilayah Kerja (PDWK) terhadap peningkatan kompetensi guru MTs di Kab. Bojonogoro.

Sejalan dengan tujuan penelitian, maka hipotesis yang akan diuji adalah Pelatihan TIK di Wilayah Kerja (PDWK) efektif terhadap peningkatan kompetensi guru MTs di Kab. Bojonogoro.

\section{METODE PENELITIAN}

Jenis penelitian ini adalah pre-experimental dengan desain penelitian one group pretestpostest design (Sugiyono, 2013). Rancangan ini dapat digambarkan sebagai berikut.

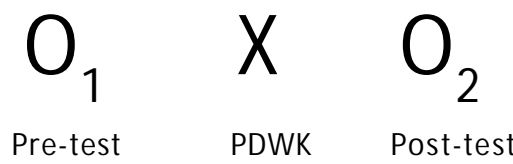

Gambar 1 Desain Penelitian

Rancangan one group pretest-postest design dipilih untuk tujuan mengetahui efektivitas perlakuan terhadap variabel dependen (Sugiyono, 2013). Dalam penelitian ini satu kelompok subjek diberikan perlakuan pelatihan TIK. Hal yang dinilai pada subjek ini efektivitas pelatihan dilihat dari hasil nilai penguasaan konsep. Penilaian penguasaan konsep dilakukan sebelum pelaksanaan pelatihan TIK dilambangkan dengan $0_{1}$ (pre-test), dan penilaian setelah pelatihan TIK dilambangkan dengan $\mathrm{O}_{2}$ (post-test). Populasi penelitian adalah semua peserta pelatihan yang berjumlah 30 orang.

Analisis keefektifan Pelatihan TIK di Wilayah Kerja (PDWK) didukung oleh hasil analisis tiga komponen keefektifan, yaitu: [1] aktivitas peserta, [2] penguasaan konsep, [3] respon peserta terhadap pelatihan. Teknik analisis data yang digunakan berbeda-beda tergantung pada tujuan yang ingin dicapai, penggunaan teknik analisis data sesuai dengan tujuan penelitian diuraikan secara singkat berikut ini.

\section{1] Observasi Aktivitas Peserta}

Untuk mengetahui seberapa besar keaktifan peserta dalam mengikuti pelatihan, maka analisis dilakukan pada instrumen lembar observasi dengan menggunakan rumus-rumus melalui persentase.

Adapun perhitungan persentase keaktifan pembelajaran peserta dalam mengikuti proses belajar sebagai berikut.

$$
P=\frac{\sum R}{\sum N} 100 \%
$$

Keterangan

$\mathrm{P} \quad=$ persentase aktivitas peserta

= jumlah frekuensi kategori observasi

=jumlah frekuensi seluruh kategori observasi

Kriteria persentase aktivitas peserta dalam proses pembelajaran yang dikutip (Yahya $\&$ Bakri, 2017) di sajikan dalam Tabel. 2 berikut.

Tabel 1. Kriteria Aktivitas Peserta

\begin{tabular}{|c|l|}
\hline Persentase & \multicolumn{1}{|c|}{ Kriteria } \\
\hline $75 \%-100 \%$ & Sangat tinggi \\
$50 \%-74,99 \%$ & Tinggi \\
$25 \%-49,99 \%$ & Sedang \\
$0 \%-24,99 \%$ & Rendah \\
\hline
\end{tabular}

2] Penguasaan konsep

Untuk mengetahui signifikansi peningkatan penguasaan konsep pemanfaatan TIK antara uji awal dan uji akhir (pre-test dan post-test), digunakan uji-t sampel berpasangan (paired sample t-test). Teknik analisis data untuk uji-t sampel berpasangan

\section{3] Angket Respon Peserta}

Data hasil respon yang diberikan peserta dianalisis dengan menggunakan analisis deskriptif kualitatif berupa presentase. Persentase tiap respon dihitung dengan menggunakan rumus berikut ini.

$\%$ Respon $=\left(\frac{\text { jumlah aspek yang muncul }}{\text { Jumlah siswa }}\right) \times 100$

Persentase respon peserta diadaptasi dari (Riduwan, 2010) dengan kriteria sebagai berikut dikutip (Yahya \& Bakri, 2017). 
Tabel 2 Respon Peserta

\begin{tabular}{|l|l|}
\hline \multicolumn{1}{|c|}{ Persenta se } & \multicolumn{1}{|c|}{ Kriteria } \\
\hline $75 \%-100 \%$ & Sangat tinggi \\
$50 \%-74,99 \%$ & Tinggi \\
$25 \%-49,99 \%$ & Sedang \\
$0 \%-24,99 \%$ & Rendah \\
\hline
\end{tabular}

\section{TEMUAN DAN PEMBAHASAN}

\section{A. Temuan}

Berikut ini diuraikan hasil uji keefektifan Pelatihan TIK di Wilayah Kerja (PDWK) yang meliputi aspek, [1] aktivitas peserta, [2] penguasaan konsep, (3) respon peserta terhadap pelatihan, penjelasan masing-masing aspek disajikan berikut ini.

1] Analisis Aktivitas Peserta

Data hasil pengamatan terhadap aktivitas peserta selama lima kali pertemuan, Perhitungan penentuan rerata dari prosentase hasil pengamatan hasilnya disajikan pada Tabel 3. berikut ini.

Tabel 3 Rerata Hasil Pengamatan Aktivitas Peserta

\begin{tabular}{|c|l|c|l|}
\hline No & Aspek yang dinilai & \multicolumn{2}{|c|}{$\%$ skor aktivitas } \\
\cline { 2 - 4 } 1 & $\begin{array}{l}\text { Rerata } \\
\text { mentusiasme dalam } \\
\text { pelatihan }\end{array}$ & 82,66 & $\begin{array}{l}\text { Sangat } \\
\text { tinggi }\end{array}$ \\
\hline 2 & $\begin{array}{l}\text { Aktivitas } \\
\text { melakukan } \\
\text { kegiatan praktek }\end{array}$ & 80 & $\begin{array}{l}\text { Sangat } \\
\text { tinggi }\end{array}$ \\
\hline 3 & $\begin{array}{l}\text { aktivitas menyam } \\
\text { paikan laporan } \\
\text { hasil/presentasi }\end{array}$ & 74,732 & Tinggi \\
\hline
\end{tabular}

Dilihat dari Tabel 3. jika dirujuk pada kriteria aktivitas peserta yang didapatkan hasil $79,14 \%$ masuk dalam kriteria sangat tinggi.

\section{2] Analisis Penguasaan Konsep}

Uji-t berpasangan digunakan untuk mengetahui apakah ada peningkatan penguasaan konsep pemanfaatan TIK yang signifikan antara pre-test dan post-test. Signifikansi peningkatan antara pre-test dan post-test tersebut mengambarkan dampak positif yang signifikan dari hasil penerapan Pelatihan TIK di Wilayah Kerja (PDWK).
Tabel 4 Hasil Uji-t Berpasangan

\begin{tabular}{|c|c|c|c|}
\hline Kelas & T & df & Sig. (2-tailed) \\
\hline TIK & -12.455 & 29 & .000 \\
\hline
\end{tabular}

Berdasarkan Tabel 5., nilai sig. (2-tailed) sebesar $0,000<0,05$, maka dapat disimpulkan $\mathrm{HO}$ ditolak sehingga diambil kesimpulannya Pelatihan TIK di Wilayah Kerja (PDWK) efektif terhadap peningkatan kompetensi guru.

\section{3] Analisis Respon Peserta}

Keefektifan Pelatihan TIK di Wilayah Kerja (PDWK) didukung juga dengan respon peserta terhadap penyelenggaraan pelatihan, secara singkat disajikan pada tabel 5 berikut ini:

Tabel 5 Hasil Respon Peserta

\begin{tabular}{|l|l|l|}
\hline No & Aspek yang direspon & $\begin{array}{c}\text { Respon } \\
\text { Peserta (\%) }\end{array}$ \\
\hline 1 & Penetapan peserta & 88,89 \\
2 & Pelayanan kepanitiaan & 90,18 \\
3 & Kedisiplinan panitia & 91,67 \\
4 & Sikap terhadap peserta & 94,25 \\
5 & Pelayanan dan Akomodasi & 92,54 \\
6 & Sarana pelatihan & 91,25 \\
7 & Kurikulum Pelatihan TIK & 90,43 \\
8 & Pengampu Pelatihan & \\
& (Widyaiswara) & 92,12 \\
\hline
\end{tabular}

Dari Tabel 5. menunjukkan bahwa pada umumnya, respon peserta terhadap Pelatihan TIK di Wilayah Kerja (PDWK) tersebut memiliki kecenderungan positif dengan persentase rerata hasil $91,41 \%$ dengan kriteria sangat tinggi.

\section{B. Pembahasan}

Kriteria keefektifan dalam penelitian ini ditentukan tiga hal, yaitu: 1] aktivitas peserta, 2] penguasaan konsep, 3] respon peserta. Data hasil uji coba menunjukkan bahwa kriteria keef ektifan telah terpenuhi. Walaupun demikian, berikut ini akan didiskusikan hasil-hasil penelitian terkait keefektifan Pelatihan TIK di Wilayah Kerja (PDWK) terhadap kompetensi Guru MTs di Kab. Bojonegoro. Aktivitas peserta yang menjadi fokus pengamatan selama kegiatan pelatihan terdiri atas sembilan tiga, yaitu: [1] antusiasme dalam mengikuti pelatihan; [2] aktivitas dalam melakukan kegiatan praktek; dan [3] aktivitas dalam menyampaikan laporan hasil/ presentasi. 


\section{Aktivitas peserta}

Berdasarkan Tabel 3. dapat dilihat bahwa aktivitas tertinggi peserta adalah kesiapan peserta menerima materi dengan rerata $82,66 \%$ ini menunjukkan peserta memiliki antusiame yang baik untuk melakukan mengikuti pelatihan ini dibuktikan dengan kedisplinan dalam kehadiran, rasa ingin tahu dan mencoba tinggi serta keseriusan dalam mengikuti pembelajaran, ini terbukti pada saat peserta melakukan aktivitas dalam kegiatan praktek dengan rerata $80 \%$. Saat kegiatan praktek semua peserta memiliki antusias yang tinggi untuk bisa mencoba pengetahuan dan ketrampilan baru yang di ajarkan widyaiswara. Sehingga diakhir pembelajaran setiap peserta menghasilkan produk berupa konten maupun media pembelajaran. Namun untuk aspek ketiga yaitu, aktivitas peserta dalam menyampaikan hasil diskusi mendapat rerata 74,73\% masuk kategori tinggi, ini dikarenakan tidak semua peserta pelatihan punya rasa percaya diri yang tinggi untuk bisa menyampaikan hasil karyanya melalui presentasi, sehingga pada saat kegiatan penyajian hasil/ presentasi widyaiswara mengalami kesulitan meminta peserta tampil ke depan dengan berbagai alasan alhasil peserta yang maju didominasi oleh orang yang sama. Berdasarkan deskripsi dan analisis hasil penelitian terlihat bahwa aktivitas peserta selama lima pertemuan termasuk dalam kategori sangat tinggi dengan skor rata-rata 79,14\%.

\section{Penguasaan Konsep}

Kriteria keefektifan yang kedua tentang penguasaan konsep tentang pemanfaatan TIK, tes penguasaan konsep berbentuk soal pilihan ganda dengan 40 item butir soal yang diberikan pada awal dan akhir pembelajaran. Pendiskripsian penguasaan konsep dengan penggunaan uji-t berpasangan (paired sample t-test), Uji-t berpasangan digunakan untuk mengetahui apakah ada peningkatan penguasaan konsep yang signifikan antara tes awal dan tes akhir. Berdasarkan hasil pengujian rata-rata antara tes awal dan tes akhir dengan menggunakan uji-t berpasangan seperti yang ditunjukkan pada Tabel 4., ternyata Pelatihan TIK di Wilayah Kerja (PDWK) dapat meningkatkan penguasaan konsep peserta secara signifikan, pada á $=0,05$. Sehingga bisa disimpulkan Pelatihan di Wilayah Kerja (PDWK) efektif terhadap peningkatan kompetensi guru.

\section{Respon Peserta}

Kriteria terakhir yang terkait dengan keefektifan adalah respon peserta, hasil dari angket respon peserta, hal ini ditunjukkan oleh data dalam Tabel 5. yaitu: [1] Penetapan peserta $88,89 \%$ peserta menyatakan bahwa penetapan peserta sudah sesuai, namun perlu ditambah lagi supaya lebih banyak lagi guru yang bisa mengikuti pelatihan; [2] Pelayanan kepanitiaan, $90,18 \%$ peserta menyatakan senang dengan pelayanan yang diberikan oleh panitia, kebutuhan mereka bisa terlayani dengan baik. Panitia juga selalu mendampingi setiap harinya dikelas selama proses pembelajaran; [3] 91,67 \% peserta menilai kedisiplinan panitia sangat baik, ini ditandai dengan kehadiran panitia selalu awal waktu kegiatan pembelajaran serta selesainya kegiatan pembelajaran sesuai dengan yang sudah dijadwalkan; [4] Sikap terhadap peserta diberikan nilai $94,25 \%$, peserta setuju apabila panitia selama melayani mereka bersikap baik dan santun; [5] 92,54 \% merasa puas dengan pelayanan dan akomodasi yang didapat, karena selain mendapatkan pelayanan konsumsi yang layak dan ATK peserta juga mendapatkan transport dan uang saku yang nilanya sesuai standar baku minimal; [6] Sarana pelatihan 91,25\% peserta merespon bahwa sarana pelatihan sudah memadai, ini dibuktikan dengan ruangan pelatihan yang luas dan nyaman sehingga memenuhi protokol kesehatan, tersedia sarana pembelajaran (LCD) dalam kondisi baik sehingga materi bisa tertransfer secara jelas kepada peserta; [7] kurikulum pembelajaran TIK yang digunakan ternyata direspon baik oleh mayoritas peserta. Menurut 90,43\% peserta kurikulum yang dipakai sangat sesuai dengan kebutuhan belajar mereka. Sehingga tujuan pembelajaran bisa tercapai dengan baik, meskipun dalam pelatihan ada beberapa materi suplemen sebagai pengayaan dari materi yang disampaikan namun hal tersebut direspon dengan baik 
oleh peserta sehingga semakin menambah antusiasme mereka dalam belajar, materi yang disampaikan juga sesuai dengan perkembangan teknologi/ kekinian; [8] pengampu pelatihan (Widyaiswara) oleh $92 \%$ peserta diberikan respon baik, widyaiswara dinilai mampu menyampaikan materi dengan baik, mengunakan media yang sesuai serta dengan baik membimbing peserta melakukan praktek pembelajaran.

Instrumen angket respon peserta terhadap pelatihan juga menggali informasi secara terbuka tentang hal-hal yang baik dan perlu dipertahankan dalam pelaksanaan Pelatihan di wilayah Kerja (PDWK). Di samping itu, dalam instrumen tersebut juga dijaring informasi tentang hal-hal yang masih kurang dan perlu dibenahi dalam Pelatihan di wilayah Kerja (PDWK). Secara keseluruhan rerata respon peserta adalah 91,41 \% ini berarti peserta memiliki respon yang sangat baik terhadap Pelatihan di wilayah Kerja (PDWK).

Respon peserta terkait hal-hal yang sudah baik dan perlu dipertahankan dalam Pelatihan TIK di wilayah Kerja (PDWK), antara lain: [1] kedisiplinan panitia, [2] cara pembelajaran TIK sudah bagus, tidak membuat jenuh, menarik, dan tidak membosankan, dan [3] penerapan Pelatihan di wilayah Kerja (PDWK) dirasakan peserta menambah ilmu dan proses pembelajaran juga bagus.

Disamping ada respon yang sifatnya perlu dipertahankan dalam pelaksanaan pelatihan, ada juga yang sifatnya perlu dijadikan pertimbangan dalam perbaikan pelaksanaan pelatihan. Respon yang masih kurang yang diberikan oleh peserta dan perlu diperbaiki, antara lain: [1] penetapan peserta, [2] kurikulum pelatihan agar selalu uptodate sesuai perkembangan teknologi.

\section{PENUTUP}

\section{A. Simpulan}

Berdasarkan hasil penelitian dan pembahasan, maka dapat disimpulkan bahwa Pelatihan TIK di Wilayah Kerja efektif meningkatkan kompetensi guru ditinjau dari aktivitas peserta, penguasaan konsep pemanfaatan TIK, dan respon peserta terhadap pelatihan. Ketiga kriteria' tersebut telah mencapai batas minimal tingkat ketercapaian yang diprasyaratkan, dengan hasil sebagai berikut.

1] Aktivitas peserta dengan rata-rata hasil pengamatan sebesar 79,14\% dengan kriteria sangat tinggi.

2] Kriteria penguasaan konsep tentang pemanfaatan TIK diperoleh nilai p-value sebesar $0,000<0,05$, dapat dinyatakan Pelatihan TIK di Wilayah Kerja (PDWK) efektif terhadap peningkatan kompetensi guru.

3] Respon peserta positif, ditunjukkan dengan rerata hasil respon $79,14 \%$ dengan kriteria sangat tinggi.

\section{B. Rekomendasi}

1. Pelatihan TIK di Wilayah Kerja (PDWK) memberikan dampak yang positif dan terjadi perbaikanperbaikan terkait kompetensi guru. Untuk itu kepada Balai Diklat Keagamaan Surabaya supaya memperbanyak diklat sejenis di wilayah lain.

2. Kegiatan Pelatihan TIK di Wilayah Kerja (PDWK) yang dilaksanakan berjalan sangat efektif seharus nya dijadikan model pendidikan dan pelatihan juga untuk pembinaan guru yang berbasis KKG dan MGMP pada satuan pendidikan. $[\alpha]$

\section{DAFTAR PUSTAKA}

Anita, N., Puspitasari, T. D., \& Habibi, A. (2016). Pengembangan Dan Peningkatan Kompetensi Guru Dalam Membuat Media Pembelajaran. Seminar Hasil Penelitian dan Pengabdian Masyarakat Dana BOPTN Tahun 2016, (hal. 164 -167). Jember.

Fajar, M., \& dkk. (2017). MENINGKATKAN KOMPETENSI GURU SMA DAN SEDERAJAT MELALUI PELATIHAN PEMBELAJARAN BERBASIS TIK. Ethos (JurnalPenelitian dan Pengabdian Masyarakat), 175-181.

Fatma Dewi, W. A. (2020). DAMPAK COVID-19 TERHADAP IMPLEMENTASI PEMBELAJARAN DARING DI SEKOLAH DASAR. EDUKATIF: JURNAL ILMU PENDIDIKAN, Volume 2 Nomor 1 April 2020 Halm 55-61. 
Faustino Cardoso, G (2003). Manajemen Sumber Daya Manusia. Yogyakarta: C.V ANDI OFFEST.

Firdaus, F. (2012). Teknologi Dalam Pembelajaran. Jakarta: Lembaga Administrasi Negara.

Hake, \& R, R. (2002). Interactive Engangment Methods Introductory Mechanic Course. Journal of Physics Education Research .Vol 66.

Kunandar. (2007). Guru Profesional Implementasi KTSP dan Persiapan Menghadapi Sertifikasi Guru. Jakarta: Rajagrafindo Persada.

Mulyasa, E. (2007). Standar Kompetensi dan Sertifikasi Guru. Bandung: Remaja Rosdakarya.

Mustofa. (2007). Upaya Pengembangan Profesionalisme Guru Di Indonesia. Yogyakarta: Universitas Negeri Yogyakarta .

Nuraeni, L. \& \& Riyanto, A. (2017). EFEKTIVITAS DIKLAT BERJ ENJ ANG TINGKAT DASAR TERHADAP PENINGKATAN KOMPETENSI PEDAGOGIK PENDIDIK PAUD. Jurnal IImiah UPT P2M STKIP Siliwangi, Vo. 5 No. 1.

Paramita , R. (2021, April 25). https:/ / lokadata. id/ artikel/ rapor-guru-dalam-hasil-uji-kompetensi. Diambil kembali dari https:// lokadata.id/ .

Riduwan. (2010). Skala Pengukuran Variabel-variabel Penelitian. Bandung: Alfabeta.

Roestiyah, N. (1999). Masalah-Masalah Ilmu Keguruan. Jakarta: Bina Aksara.

Satariyah. (2021, April 20). https: / / bdkjakarta.kemenag.go. id/ berita/ tantangan-guru-gagap-teknologipada-pembelajaran-jarak-jauh. Diambil kembali dari https:// bdkjakarta.kemenag.go.id.

Saud, U. S. (2009). Pengembangan Profesi Guru. Bandung: CV. Alfabeta.

Sugiyono. (2013). Metode Penelitian Kombinasi (Mixed Methods). Bandung: CV. Alfabeta.

Sujarwoto, G (2020, April). https:/ / pusdatin. kemdikbud. go.id/ pembelajaran-online-di-tengah-pandemi-covid19-tantangan-yang-mendewasakan/ . Diambil kembali dari https:// pusdatin. kemdikbud.go.id: https:/ / pusdatin.kemdikbud.go.id/ pembelajaran-online-di-tengah-pandemi-covid-19-tantangan-yangmendewasakan/

Suriansyah, A. (2015). PENGEMBANGAN PEMBELAJARAN BERBASIS TIK (PROSES DAN PERMASALAHANNYA). Jurnal Paradigma, Volume 10, Nomor 2, Juli 2015.

UU RI No. 14 Th. 2005 tentang Guru dan Dosen. Jakarta: Sinar Grafika. (2006).

Wardinur, \& Mutawally, F. (2019). Peningkatan Kompetensi Guru Melalui Pelatihan Pemanfaatan Teknologi sebagai Media Pendukung Pembelajaran di MAN 1 Pidie . Jurnal Sosiologi USK, Volume 13, Nomor 2, Desember 2019.

Yahya, A., \& Bakri, N. W. (2017). Penerapan Model Kooperatif Student Teams Achievement Divisions untuk Meningkatkan Hasil Belajar Siswa . JURNAL SAINTIFIK, JULI 2017 VOL . 3 NO. 2,.

Yamin, \& dkk. (2014). SPSS Complete: Teknik Analisis Terlengkap dengan Software SPSS. Jakarta: Salemba Infotek.

Yonny, A., \& dkk. (2010). Menyusun Penelitian Tindakan Kelas. Yogyakarta: Familia.

Yusrizal, Safiah, I., \& Nurhaidah. (2017). KOMPETENSI GURU DALAM MEMANFAATKAN MEDIA PEMBELAJARAN BERBASIS TEKNOLOGI INFORMASI DAN KOMUNIKASI (TIK) DI SD NEGERI 16 BANDA ACEH. urnal IImiah Pendidikan Guru Sekolah Dasar, FKIP Unsyiah Volume 2 Nomor 2, 126- 134. 